\title{
Journal of Biochemistry Education
}

\section{EXPERIMENTAL MICROBIOLOGY: INVESTIGATING AND PROPOSING TEACHING OPTIONS IN A HIGH SCHOOL IN FRONTEIRAS-PI}

\author{
MICROBIOLOGIA EXPERIMENTAL: INVESTIGANDO E PROPONDO OPÇÕES DE ENSINO NUMA \\ ESCOLA DE ENSINO MÉDIO EM FRONTEIRAS - PI.
}

\begin{abstract}
Microbiology is a branch of biology that studies the microscopic universe from microorganisms to the way they work. Microbiology is a complex science for teaching without practicing. The absence of more accessible didactic material between society and microbiology hinders the dynamism of this important subject. Therefore, the aim of this study is to provide the coexistence of practical microbiology activities for high school students from the public school in Fronteiras, Piauí, Brazil. To carry out this work, three practical activities were performed at low cost and adapted to the students' reality, in addition to a whole theoretical explanation to link theory and practice. Two questionnaires were applied, one before and one after the activities, to raise students' prior knowledge about microorganisms and the influence of practices on them. The results indicated that the students had little knowledge about basic microbiology and had previously had access to negative information about microorganisms. After carrying out the activities, it was possible to observe a positive change in this thinking. Most of the data compiled in the tests proves that most students understood more about microbes in the end and gained basic knowledge about microbiology.
\end{abstract}

Keywords: Microorganisms; practical activities; lectures.

\section{Resumo}

Microbiologia é um ramo da biologia que estuda o universo microscópico desde os microorganismos até à maneira como eles funcionam. Microbiologia é uma ciência complexa para o ensino sem praticar. A ausência de material didático mais acessível entre a sociedade e a microbiologia dificulta o dinamismo desse importante assunto. Portanto, o objetivo deste estudo é proporcionar a coexistência de atividades práticas de microbiologia para alunos do ensino médio da escola pública de Fronteiras, Piauí, Brasil. Para a realização deste trabalho, três atividades práticas foram realizadas a baixo custo e adaptadas à realidade dos alunos, além de toda uma explicação teórica para vincular teoria e prática. Foram aplicados dois questionários, um antes e um após as atividades, para levantar o conhecimento prévio dos alunos sobre os microrganismos e a influência das práticas sobre eles. Os resultados indicaram que os estudantes possuíam pouco conhecimento sobre microbiologia básica e haviam, previamente, tido acesso a informações negativas sobre os microrganismos. Após a realização das atividades, foi possível observar uma mudança positiva nesse pensamento. A maioria dos dados compilados nos testes prova que grande parte dos estudantes entendeu mais sobre os micróbios e obteve conhecimentos básicos sobre microbiologia.

Palavras-chave: Microrganismos; atividades práticas; aulas expositivas. 
EXPERIMENTAL MICROBIOLOGY: investigating and proposing options in education

in High School in Fronteiras-PI.

Record of performed activity

Title

\section{EXPERIMENTAL MICROBIOLOGY: INVESTIGATING AND PROPOSING TEACHING OPTIONS IN A HIGH SCHOOL IN FRONTEIRAS-PI}

Target audience

Related disciplines

Educational objectives

Justification for use

\section{Worked} contents

Estimated duration

Materials used
High school in the municipality of Fronteiras - PI

\section{Microbiology}

To demonstrate the use of simple and inexpensive materials for laboratory practice classes in Microbiology.

Due to the difficulties in conducting practical activities in the teaching of microbiology and the fact that this process can influence the performance of students, the approximation of the university with the public school brings great benefits, mainly in the exchange of experiences.

Preparation of culture medium and sowing; Mold production in pieces of bread; Fermentation for alcohol production.

4 hours

Slices of bread, water and plastic bags. $100 \mathrm{~mL}$ of water, $60 \mathrm{~g}$ of sugar and $1 \mathrm{~kg}$ of yeast. A pressure cooker, 4 soda cans, craft paper and water, a nutritive medium (prepared with colorless gelatin or agar and beef broth). Plate Petri (or some domestic container), swabs. 


\section{Introduction}

The teaching of biology is successful starting on the way that the content is transmitted since biology is one of the disciplines that can capture the attention of the student due to being attractive and part of everyday life. Due to a large amount of information, the traditional form of teaching that is applied by teachers, and the fact that there is no positive parallel with regard to microorganisms, among the biology subjects taught in the classroom, microbiology both fascinates and causes fear $[1,2]$.

Data demonstrate that many students leave high school and attend higher education courses, mainly in the area of Health and Biological Sciences, with precarious knowledge, in which they reduce microorganisms to disease-causing and mold-forming. Thus, it is up to the teacher to identify the deficiencies in the students' learning, aiming to problematize and develop activities and practical situations that challenge the previous knowledge of their students, so that they develop a questioning character and start needing to find new knowledge and solutions. In the field of microbiology, the difficulties are directly related to the complexity of the content, the large amount of information needed to understand a certain topic, the abstraction of concepts, as well as the student's interest $[3,4]$.

The lack of motivation of students in biology classes is the result of a series of factors that are related both to the environment outside the school, as well as to its administrative organization, for example, the methodology applied by the teacher in the classroom. It is noteworthy that the absence of practical classes and other methodologies that include the student in the teaching and learning process has rendered learning ineffective [5]. $78 \%$ of the students have difficulties in understanding the contents of biology and only $14 \%$ of the teachers perform practical activities [6].

Biology students, as well as those who have never had the experience of this class, consider practical classes as facilitators of learning. Therefore, the importance that a well-done biology teaching has for the training of individuals is clear. In addition to making learning more interesting (thinking mainly of more complex subjects, such as microbiology), the use of practical methodologies can also contribute to the construction of the initial dimensions of scientific literacy and subsequently open new paths in this environment [7]. 
The study of the microscopic universe is important for human society [8], since microorganisms form most of the planet's biomass and are responsible for performing essential functions for the emergence and maintenance of life [9], in addition to being inserted in commerce, as in the case of food and pharmaceutical industries [10].

The basic study of microbiology in schools is of total relevance to the population, as we become more aware individuals about the importance of our daily hygiene habits, mainly because they are related to our health [11]. However, because it is a complex science and the individuals are imperceptible to the naked eye, teaching microbiology in schools without practice is a difficult task for teachers [12]. Mainly because most schools do not have the necessary equipment and laboratories for the manipulation and visualization of the organisms.

Thus, teaching microbiology in schools ends up being more theoretical, distanced from reality, and makes it difficult for students to understand [13], since it is done in an unattractive and uninteresting way [14].

In addition to this fact, microorganisms are seen, unfortunately, by the majority of the population, as agents that essentially cause serious diseases, such as AIDS [8], resulting in rejection by students and hindering their interest in the topic.

The absence of a more accessible didactic intermediary between society and microbiology hinders the dynamism of this subject, requiring the intervention of the teacher in the development of teaching and learning strategies and technologies that help to stimulate students to the knowledge of microorganisms and their applicability in their daily lives [8]. Practical activities are fundamental for the understanding, interpretation and assimilation of the contents of microbiology, capable of arousing interest in discovery and developing scientific and critical knowledge [15].

Given this, it is extremely important that practical activities that strengthen the teaching of this science be developed, seeking to meet the needs of the students [16]. Considering that just over $20 \%$ of schools in Piauí have science laboratories, and that 4,801 of them are public schools, according to data from the 2015 School Census in partnership with Instituto Unibanco, it is necessary that low cost practices be developed due to the lack of resources, as well as simple techniques be adopted [17]. In view of the difficulties in carrying out practical 
activities in the teaching of microbiology and that such a process can influence the performance of students, the approximation of the University with the Public School brings great benefits. The following project aimed to provide the experience of practical microbiology activities to high school students from the public network of Fronteiras-PI, so that they have more reflective attitudes in relation to health and the environment, as well as to evaluate students' assimilation regarding the microbiology apprehended in their socio-school daily life, and what is the influence that practical teaching can provide to facilitate their academic development.

\section{Methodology}

\section{1 Place of Study}

This study had 23 students, aged between 15 and 33 years, regularly enrolled in the Centro Estadual de Educação e Ensino Profissional Francisco Alves de Sousa - CEEP, Fronteiras, Piauí, where they were attending Technical Education.

\section{2 Application of the study}

\section{2.1 Curricular Survey}

The initial stage of the project consisted of conducting a curricular survey in these education units on the subjects covered in microbiology, as well as an informal survey together with the faculty, aiming to analyze which factors contribute to a poor teaching in the microbiological field.

The project emphasized the realization of expository classes on October 24, 2018 on general microbiology and the main microorganisms present in our daily lives, discussion groups and meetings to expose ideas and demystifications about microorganisms that are considered absolute truths.

\subsubsection{Application of questionnaires}

In this stage of the project, a semi-structured online questionnaire of quantitative character was applied through Google Forms, prior to and after the realization of practical and theoretical activities, which was answered by means of 
electronic devices through an access code. The questions were focused on everyday and school microbiology and the relationship of microorganisms with health and the environment (diseases and benefits).

The questionnaire had nine (09) objective questions which were composed by two until twelve alternatives and had the academic literature Tortora [10] and Trabulsi [18] as a main basis. Before and after the performance of the practical activities, finishing up the questionnaire application, the data were compared, and each figure represents the students' total responses.

\subsubsection{Implementation of practices in the teaching of microbiology}

An action research for the application and execution of three practices was used with the 2nd year students of the Nursing Technician and Oral Health Technician courses: mold production in breads [16], fermentation to form alcohol [19] and preparation of culture medium [13]. Aiming to demonstrate the presence of microorganisms in their daily lives, school environment, as well as in their own bodies (saliva, hands, utensils, handles, taps, sinks). The class was divided into groups and with the help of the facilitator, practical activities were carried out.

\section{3 Data Analysis}

The data on microbiology practices associated with the questionnaires were analyzed in a descriptive and comparative way. The questionnaire was applied before and after the practices and expositions of the classes, so that it was possible to understand the influence of practical actions aimed at teaching microbiology in the students' daily lives. Each questionnaire was counted, and comparative figures were generated in the Microsoft Excel $\odot$ program.

\subsection{Ethical aspects}

This project was submitted to the Ethics in Research Committee (ERC), following the recommendations incorporated in resolution 466/2012 of the National Health Council (NHC), which aims to ensure the ethical and legal precepts that relate to the study subjects, ensuring the privacy and confidentiality of the students involved in the project. Being considered approved with the number: 2959780 of the certificate of presentation for ethical appreciation - CPEA. The Term of Free 
and Clarified Consent (TFCC) was a way to clarify the informant regarding the ethical aspects.

\section{Results and discussion}

\section{1 Evaluation of the textbook}

Although the textbook highlights the importance of microorganisms briefly and succinctly, most of its contents are directly linked to issues of diseases, mainly related to bacteria and viruses. In several textbooks and handouts used by the teacher in microbiology, the diseases caused by microorganisms are emphasized [21]

Thus, it is observed that this content addressed by the Science or Biology teacher, if associated with myths, can directly influence the construction of negative concepts about microorganisms. So, it is up to the teacher to use other didactic materials and other sources that talk about the benefits of microorganisms to society.

\section{2 Report of Practical Intervention}

The dialogue between school and researcher was always positive, with the school structure being made available. The electronic equipment needed for research, such as projection equipment and the teacher of the discipline were always available to support the researcher with any difficulties that were faced.

The two classes were worked on separately, being initially exposed to a slideshow and later a conversation wheel. In which the questions were related to the theme of how microorganisms can be present in their daily lives, aiming to awaken the students' critical sense.

The relationship with the students was built gradually. Initially, some of the students were apprehensive as to participate in the research. There was also a student with a hearing impairment who refused to participate. Throughout the development of the project, the proximity and attractiveness of the practices won over the students, due to the normal absence of these practices in the discipline.

Students had difficulties in answering the questionnaires, due to not having 
electronic devices (computers, cell phones) and internet access. This problem caused a delay in making equipment available so that other students could answer the questionnaires. However, all students who were present during the activities responded to the requested questionnaires.

Regarding the proposed practices, the students were able to reproduce them efficiently. They realized how interesting it was after they were questioned about how each practice happened. The questions became clearer directly after the practices. It was clear how the practices influenced the students' perception of the subjects, as the responses to the questionnaires were well-directed when compared to the previous one. They were also able to develop elaborated and clear questions, in addition to linking the issues to their reality.

Due to the size of the class, the students dispersed very easily. Another difficulty faced was the development of practices that could be both carried out with low-cost materials as well as reproduced at home. Among the practices, the one that presented the most difficulties in being reproduced was the culture medium. Due to inappropriate structure, the risk of contamination in the incubation of the collected material could be imminent. This practice was supposed to have been performed with gelatin instead of agar, but due to the high temperatures in the region, gelatin had a lot of firmament and melting problems.

There was no difficulty regarding personal protective equipment (PPE), since these were health students, all of them already had lab coats and some oven gloves. However, for safety, equipment such as gloves and masks were provided to everyone.

\subsection{Analysis of Questionnaires A and B}

The target audience of the research was the following: students enrolled in the public high school system of the 2 nd year and students of the courses in Oral Health Technician and Nursing Technician, aged between 15 and 33 years. All studied the subject in question, and all attended high school and elementary school in public schools. Among the 23 students interviewed, 82.6\% are female, while $17.4 \%$ are male. Two students claim to work from Monday to Friday, with no fixed schedule and specific days. When asked about the existence of Science / 
Biology laboratories at school, 34.8\% responded positively, 34.8\% answered negatively and $30.4 \%$ stated that they do not know whether there is a laboratory at school. In addition, $87 \%$ never participated in anything in the area of microbiology and only $13 \%$ said they had participated, but were unable to say which activity they would have participated in.

The biology teacher and the school board stated that there are laboratories, but that they are not exclusively dedicated to biology, and due to the lack of resources to buy equipment and materials, they are hardly ever used. The biology teacher also stated that he had never performed practical activities, as confirmed by the students' report. When asked if the school had already carried out any project in the field of microbiology, $91.3 \%$ responded negatively and $8.7 \%$ responded positively, despite not knowing how to answer which project the school would have carried out.

\subsubsection{Students' knowledge of the microscopic universe}

The data from the first alternative of questionnaire $A(Q A)$ confirms the lack of knowledge or confusing and ideas about microorganisms, which may be the consequence of more theoretical teaching with fewer practical activities. With the realization of the practical activities along with the theoretical explanation, there was a change in these data as observed in questionnaire $B(Q B)$.

Mora (22) affirms that the practical activities directly influenced the teaching and learning process of concepts focused on microbiology. After performing the activities in his research, he found that the students were excited, since they were requesting new materials and seeking to remedy their doubts.

Table 1. Answers of the questions 1 and 2

\begin{tabular}{lllllll}
\hline & \multicolumn{3}{c}{ Questionnaire A } & \multicolumn{3}{l}{ Questionnaire B } \\
\hline \multicolumn{1}{c}{ QUESTIONS/ALTERNATIVES } & YES & NO & MAYBE & YES & NO & MAYBE \\
\hline $\begin{array}{l}\text { Question 1. "Do you know what } \\
\text { microorganisms are?" }\end{array}$ & $30 \%$ & $57 \%$ & $13 \%$ & $65 \%$ & $13 \%$ & $26 \%$ \\
\hline $\begin{array}{l}\text { Question 2. "Microorganisms are } \\
\text { essentially disease-causing } \\
\text { beings?" }\end{array}$ & $60.9 \%$ & 17.4 & $21.7 \%$ & $34.7 \%$ & $34.8 \%$ & $30.4 \%$ \\
\hline
\end{tabular}

In question 2, the students had to respond whether microorganisms caused 
only diseases (Table 1). This data confirms Romeiro's [23], who questioned the students if they knew what microbiology was. $80 \%$ answered yes but stated that only had diseases-related information. The importance of new methods in class or laboratory is of wide value to students because they actively participate in the learning process.

Before this questionnaire, this subject was explained and debated, with the demonstration of Practice 2, which addressed the use of microorganisms in the production of beverages, as well as the visualization of videos and images about their usefulness and benefits for the environment and society. Although the activities influenced the students as mentioned above, a good part of them $(65.2 \%)$, still do not have fixed answers on this subject.

With the results obtained from the third question (Table 2), in the questionnaire $A(Q A)$ and questionnaire $B(Q B)$, we can observe the association that the students made between hygiene habits and microorganisms. It was evidenced that after the practice of plating that students could visualize that our hands normally have a lot of microorganisms on them and should be constantly cleaned.

Table 2. Answers of question 3

\begin{tabular}{cllll}
\hline $\begin{array}{l}\text { Question 3. "What is the } \\
\text { great importance of } \\
\text { washing your hands } \\
\text { before meals?" }\end{array}$ & Questionnaire A & Questionnaire B \\
\hline & $\begin{array}{l}\text { The removal of } \\
\text { the microbes by } \\
\text { washing hands }\end{array}$ & $\begin{array}{l}\text { Meant to } \\
\text { leave } \\
\text { hands } \\
\text { clean }\end{array}$ & $\begin{array}{l}\text { The removal of } \\
\text { the microbes by } \\
\text { washing hands }\end{array}$ & $\begin{array}{l}\text { Meant to } \\
\text { hands } \\
\text { clean }\end{array}$ \\
\hline Alternatives & More than $80 \%$ & $17.4 \%$ & More than $80 \%$ & $13 \%$ \\
\hline
\end{tabular}

This finding confirms with this research that $65 \%$ of the students responded that washing their hands avoids diseases while $35 \%$ answered the opposite. So, for students, the habit of washing hands removes not only visible dirt, but also that which is not visible to the naked eye and could be a risk to their health [24].

3.3.2 Question 4 - "Check the options with the places that, in your opinion, may present bacteria."

In this question students were asked which places present bacteria. This questioning is important because it allows us to know whether the students are convinced that microorganisms, 
such as bacteria, are present practically everywhere. This way it is possible for the students to establish measures and act as aware individuals concerning their daily hygiene habits.

Figure 4. Percentage of questionnaire $A$ and questionnaire $B$ responses. Questions applied in the classes of the Nursing technician and Oral Health Technician concerning the presence of bacteria.

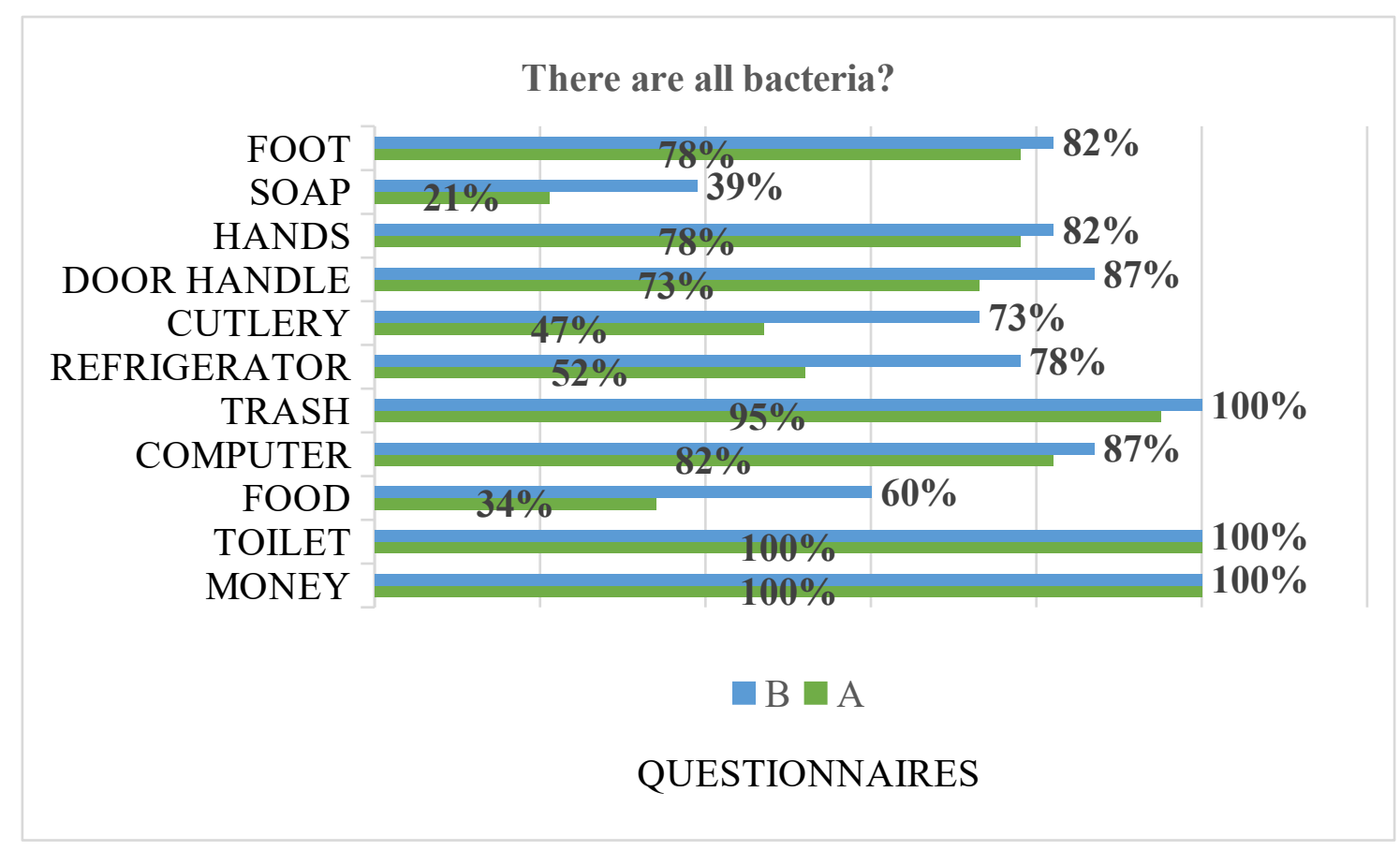

The most indicated places for the existence of bacteria in questionnaire $A$ (QA) and questionnaire (QB) were the toilet and money with $100 \%$ percentage, followed by garbage $95.7 \%(\mathrm{QA})$, and $100 \%(\mathrm{QB})$. The alternative which obtained the lowest percentage was soap, with only $21.7 \%(\mathrm{QA})$ and $39.01 \%(\mathrm{QB})$, but it is noteworthy that all the options received expressive quantities, as visualized in figure 4.

Something similar happened in a study [23] in which $90 \%$ of students said that bacteria are practically everywhere, with only a small percentage of $10 \%$ who said it depended on the place. Thus, establishing the importance of practice 3 , which allowed students to collect organic material and observe through the growth of microorganisms in the culture medium the places which in their opinion could have bacteria and that way confirming their initial thoughts.

3.3.3 Question 5 - "Check the options that present diseases transmitted by sexual intercourse."

The data show a mastery on the part of the students regarding diseases transmitted through sexual intercourse, probably because they are students of technical courses focused on health. As seen in Figure 5, the diseases that had 
the highest percentage were precisely those that have the greatest dissemination through the media [25]. When it comes to sexually transmitted diseases, $92.2 \% \pm$ $2.0 \%$ of the students (a very significant amount) said they knew the subject, precisely because it is a subject of medical importance and they are extremely contagious diseases, as is the case of AIDS (100\% Questionnaire A (QA) and Questionnaire B (QB) 95.7\%), Syphilis (QA 73.9\% and QB 56.5\%) and Gonorrhea (QA 78.3\% and QB 56.5\% ), (Figure 5).

Figure 5. Percentage of questionnaire $A$ and questionnaire $B$ responses. Applied in the classes of the Nursing Technician and Oral Health Technician concerning diseases sexually transmitted.

3.3.4 Question 6 - "Check the options that present diseases transmitted by contact with sick people."

In this question, it was possible to observe an average knowledge on the part of the students (Figure 6). The most marked diseases were chickenpox, tuberculosis, influenza $A$ and measles. This question is directly related to question 5 , and as previously mentioned, the classes stand out in this way because they are taking courses in the health field.

Another point to be highlighted is the lack of knowledge with regard to diseases transmitted by protozoa, in this case, Toxoplasmosis and Chagas' disease; diseases that are not contagious $[26,27]$ and were marked as being, so it is concluded that there is a lack of knowledge in this field. 
Figure 6. Percentage of questionnaire $A$ and questionnaire $B$ responses. Applied in the classes of the Nursing Technician and Oral Health Technician concerning diseases transmitted by contact with sick people.

\subsubsection{Question 7 - "What diseases are caused by fungi?"}

From the results obtained in this question, it is possible to notice a certain

\section{DISEASES TRANSMITTED BY CONTACT WITH SICK PEOPLE}

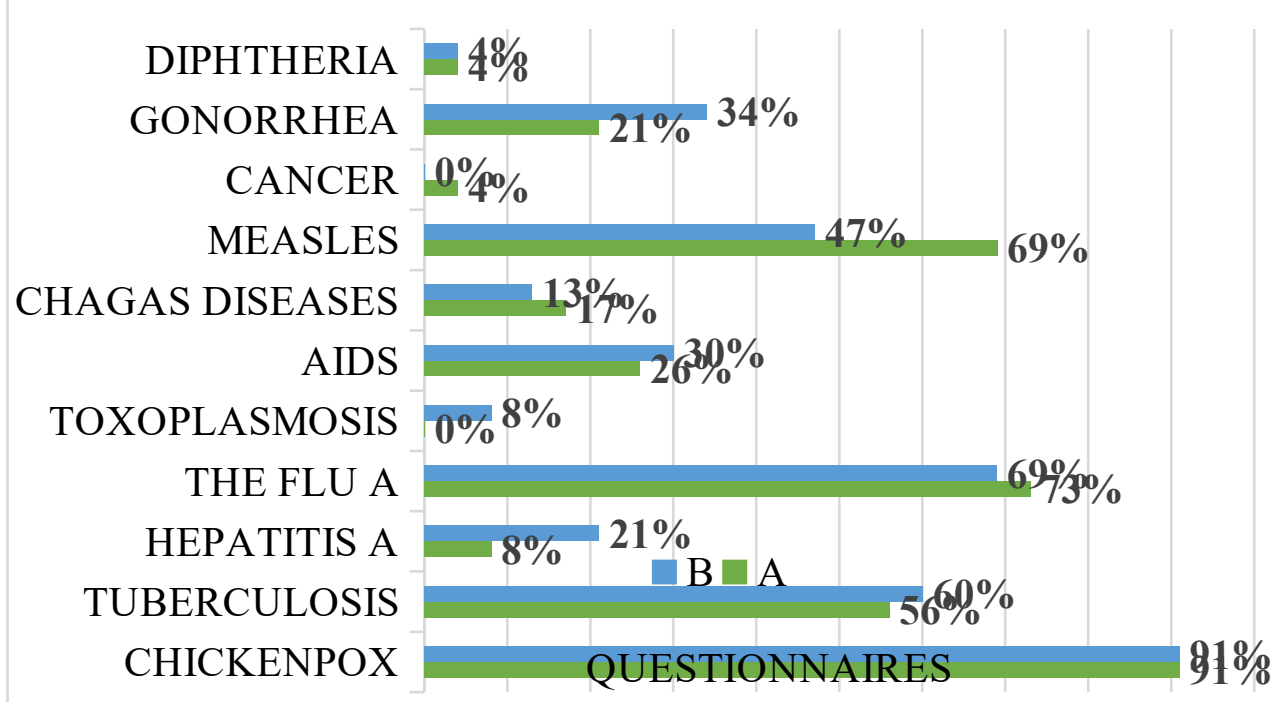

intellectual domain on the part of the students regarding fungal diseases, because as shown in Figure 7, the diseases that were most marked were Chilean and Ringworm. It was also observed that Tetanus received a percentage of $91.3 \%$ in the QA. This confusion was corrected through discussions on the subject (Figure 7 of the QB) and the percentage dropped to $4 \%$. Tetanus, as we know, is a disease transmitted by a bacterium present in the soil, which through its spores inside the host causes the muscles to tighten, possibility causing death [28].

This change in the responses demonstrates the students' learning about the difference between fungi and bacteria. But this analysis does not correspond to reality, since fungi teaching for higher education in biological and health areas are not as taught and contextualized. There is a necessity of the course about Mycology with a connection between theory and practice, thus assimilating the contents and their applicability in everyday life [29]. 
Figure 7. Percentage of questionnaire $A$ and questionnaire $B$ response. Applied in the classes of the Nursing Technician and Oral Health Technician concerning diseases caused by fungi.

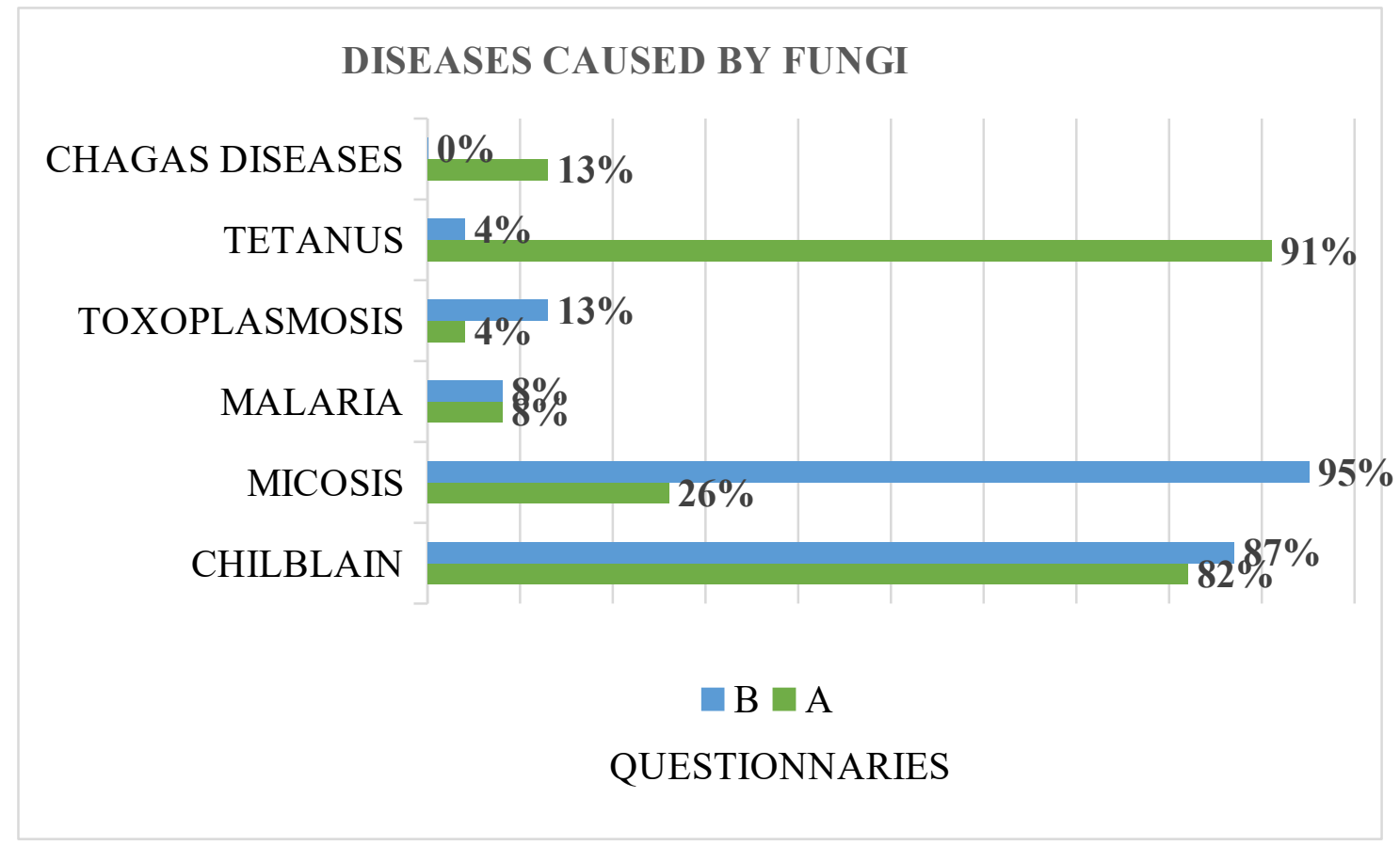

\subsubsection{Question 8 - "Are viruses' beings that possess life? If the answer is yes, describe below. "}

The viruses are considered non-living beings by many researchers because they can only replicate after penetrating the genetic machinery of cells and do not possess a cellular structure, however, there is more and more evidence that these organisms have life, such as its ability to invade other viral structures and cause disease.

Based on the theory of the origin of the species described by Charles Darwin, viruses are defined as living beings, because they present DNA or RNA and have high adaptability and evolution. A recent example to present was what occurred with H1N1 virus, which due to genetic mutations suffered in its DNA because of its ability to associate with genes derived from animals, evolved from influenza to $\mathrm{H} 1 \mathrm{~N} 1$ influenza, causing the first pandemic of the $21^{\text {st }}$ century [30].

Presently, viruses are being discussed worldwide because of the COVID 19 pandemic. In the classroom this is a subject which raises a lot of doubts. Since viruses are different from all other microorganisms, these beings almost lack biological structures and cause a large number of deaths and destabilization in 
humanity because of its effective transmission (31).

Figure 8. Percentage of questionnaire $A$ and questionnaire $B$ responses. Applied in the classes of the Nursing Technician and Oral Health Technician.

\section{Whether viruses have life}

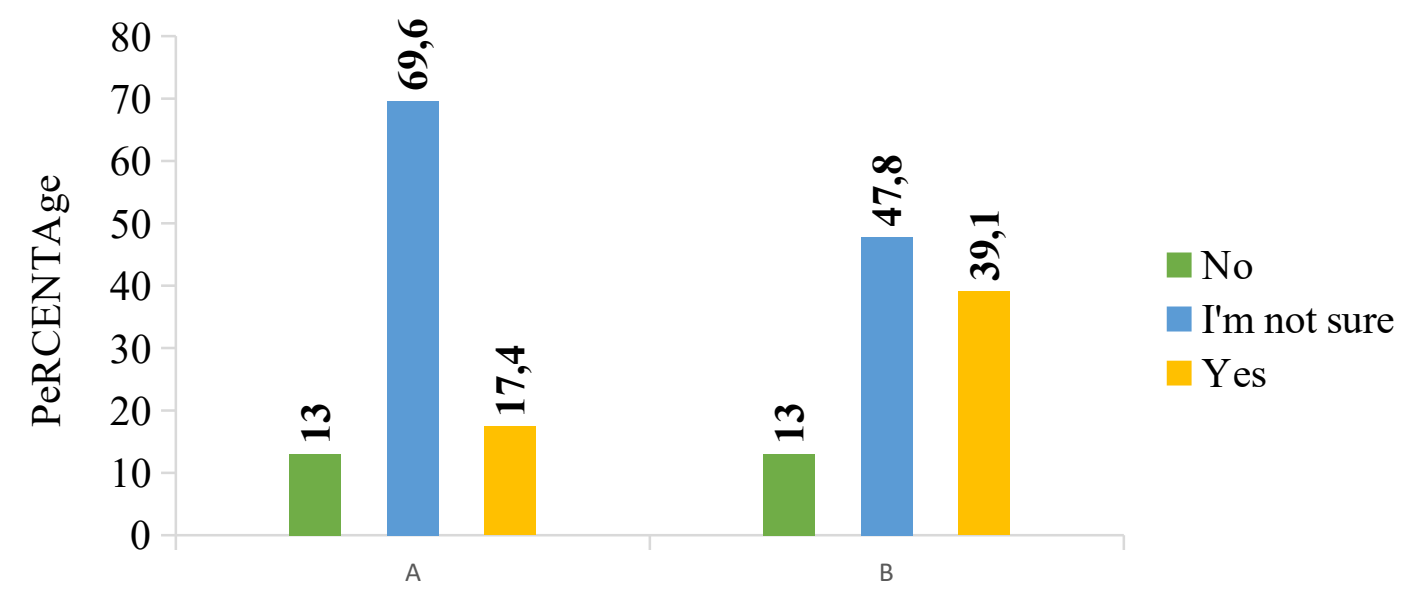

QUESTIONnaireS

According with the results illustrated in figure 8 , it is visible that all this uncertainty on account of whether the viruses have life or not, is being reflected on the teaching, because of the two outcomes obtained in questionnaires $A$ and $B$, the majority of students stated not to be sure about this question, with $69.6 \%$ in the $\mathrm{QA}$ and $47.8 \%$ in the $\mathrm{QB}$. There was no significant change between $\mathrm{QA}$ and $\mathrm{QB}$ because this is a subject that requires further study and discussion of details. It leaves space for a whole new research proposal based on its current relevance. For example, a development research with the use of cell phones like an instrument for knowledge concerning viruses and vectors [32].

\subsubsection{Question 9 - "Can microorganisms only be seen with the help of the microscope?"}

Microorganisms are microscopic organisms that can only be seen through microscopy techniques. With the results obtained, it is evidenced that most of the students are convinced about this assertion, with $82.6 \%$ of percentage, followed by $4.4 \%$ negative to this statement and $13 \%$ that are not sure.

After the practices were performed with the help of microscopic light, including the whole theoretical explanation, these numbers became absolute, with $100 \%$ of the answers aimed at affirming that these beings can only be visualized 
utilizing techniques of microscopy. It is concluded that the participation of students in practical classes is very important to clarify doubts regarding this microscopic universe.

Figure 9. Percentage of questionnaire $A$ and questionnaire $B$ responses. Applied in the classes of the Nursing Technician and Oral Health Technician.

Microbiological experimentation promotes both developments, as well as the interaction between teachers and students, so that it gives students more

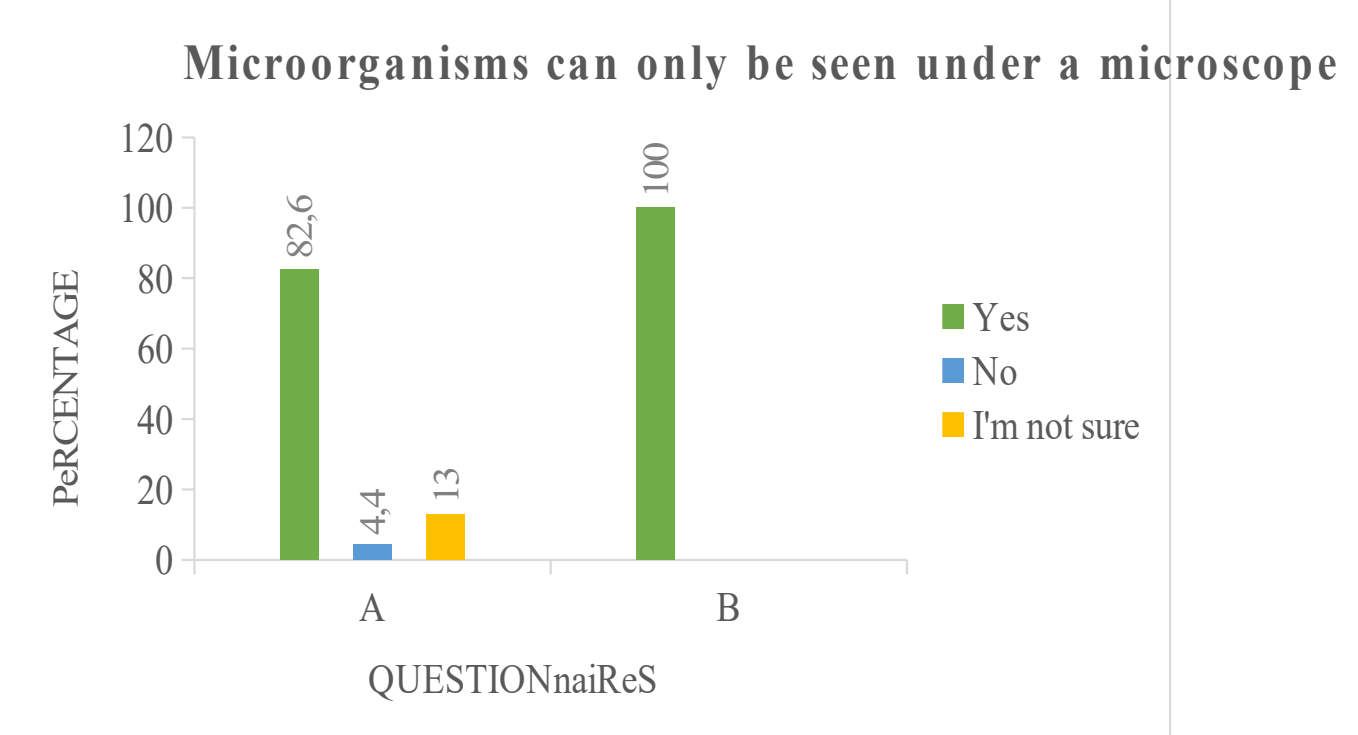

autonomy to make decisions and solve problematic situations when they are able to bring Biology Teaching concepts and theories closer to everyday situations. Experimentation supports students' critical sense, not to mention that these practical activities are essential to stimulate learning. Strategies such as experimental classes, videos, models, and others are resource options that provide more effective learning [33, 34].

There were difficulties in this association as previously observed, but it was possible to perform the practice, and it is visible to the teacher that it is possible to perform similar activities, when the teaching unit does not provide a structure, as well as equipment suitable for its realization. Thus, the use of practical activities together with the theory provides more pleasant and less monotonous teaching for the student. 


\section{Conclusion}

With the compilation of data related to $Q A$ and $Q B$, it was possible to identify the prior knowledge of students in the 2nd year of the Technical Course in Oral Health and the Technical Nursing Course about microorganisms and microbiology in general.

Through the QA, it was observed the lack of basic knowledge of the students regarding the subjects mentioned above. However, the association between the expository class and the practical class was crucial for the students' learning, in addition to clarifying doubts about microbes, in a way influenced by the didactic material for presenting more content aimed at the pathogenicity of microorganisms than their environmental benefits. and commercial.

Through the QB information, it was possible to confirm the effectiveness of using practical activities for the development of more effective and interesting learning, confirming the information previously mentioned. With the effective participation of students in the face of practical activities, it was possible to establish collectivity among their classmates, in addition to their interest in the discovery of the microscopic universe and the main scientific techniques that surround them. In addition to visualizing and understanding the importance of daily hygiene, for the elimination of microbes that could be offensive to your health.

The classes showed to have good knowledge regarding the diseases covered in the questionnaires, with only a few errors in relation to the diseases caused by protozoa. This basic knowledge is a consequence of being taking technical courses focused on health.

Simple and low-cost material and procedures were essential for the success of practical activities, despite the short time available and some difficulties with adapting these techniques to your reality. This set is highly effective and is an important tool to be used by the teacher in microbiology classes.

The research provided an intellectual and cultural maturation both for the university student on the microbiological field, as well as for his training as a professor of biology. The use of new methods and techniques favors teaching innovation, facilitating the work of the teacher, as well as contributing to the teaching and learning process to occur more efficiently. 


\section{References}

[1] Krasilchik M. Practice of teaching Biology.Edusp, 4a ed. P. 11, 2004.-Google Search. 4a ed. Edusp; 2004.11 p.

[2] Oliveira, N. F.; Azevedo, T. M.; Neto, L. S. Alternative conceptions about microorganisms: alert to the need for improvement in the teaching-learning process of biology. revistas.utfpr.edu.br [Internet]. Brazilian Journal of Science and Technology Education, Ponta Grossa, 2016; 9 (1): 260-276. [cited 2019 June 3]; Available from https://revistas.utfpr.edu.br/rbect/article/view/2031

[3] ABBAS GG, Braga RPS; Gomes V. Knowledge of the students about microorganisms and their use in daily life. Journal of Education, Science, and Mathematics, 2012, 2(1), 60 [Internet]. [Cited 2019 June 3]; Available from http://publicacoes.unigranrio.edu.br/index.php/recm/article/view/1913

[4] Teodoro N C; Campos L M L. The Professor of biology and difficulties with the teaching contents. Rev of SBEnBio. 2016;(9): 5391.

[5] Birth A P C, Araújo N S. Learning difficulties of students in the teaching of biology: a reflection from theoretical substrates and researches in a public school of Parnaíba/PI [Internet]. Universidade Federal do Piauí - UFPI/Campus Minister Reis Velloso. 2014: 1-5 in.[cited 2019 Jun 4]. Available from: http://www.scielo.br/pdf/ensaio/v14n52/a08v1452

[6] Silva F S S, Morais L J O, Cunha I P R. Difficulties of biology teachers in teaching practical classes in public and private schools in the municipality of Imperatriz (MA). REV UNI, Empress [Internet].2011, 1 (1): 135 - 49. [Cited 2019 Jun 4] Available from http://www2.ifrn.edu.br/ojs/index.php/HOLOS/article/view/1724

[7] Lima D B, Garcia R N. An investigation into the importance of the practical classes of biology in high school. Application Notebooks, 2011, 24 (1): 201-224, 2011. [Internet]. [Cited 2019 June 3]; Available from https://www.seer.ufrgs.br/CadernosdoAplicacao/article/view/22262

[8] KIMURA, A. H.; OLIVEIRA, G. S.et al. Microbiology for secondary and Technical education: contribution of extension to teaching and application of science. UEPG Connection Magazine. 2013, 9 (2).

[9] Madigan M, Martinko J, Bender K, Buckley D. Microbiology of Brock-14a edition, 2016

[10] Tortora G J, Funke B R, Case C L. Microbiology. 12th edition. Artmed Editora. 2016, 939.

[11] Hensel CF. Micro-Organisms in our life: a problematizing approach. The Federal University of Mato Grosso do Sul-UFMS, Campo Grande; 2016.

[12] Limberger $\mathrm{K} \mathrm{M}$, SILVA R M, ROSITO B A. Investigating the contribution of 
experimental activities in the conceptions about the microbiology of elementary school students. [Internet]. Faculty of Biosciences, Pontifical Catholic University of Rio Grande do Sul. X Scientific Initiation Salon PUCRS. 2009, p. 228. [Cited 2019 Jun 4]. Available from: http://www.pucrs.br/edipucrs/XSalaolC/Ciencias_Biologicas/Educacao_em_Biologi a/71426-KAREN_MARTINS_LIMBERGER.pdf

[13] Antunes C H, Pileggi, Mazda A K. Because the scientific view of microbiology does not have the same focus on the perception of microbiology in high school. has [Internet]. Minutes of III Third National Symposium on Science and Technology education. 2012. [cited 2019 Jun 4]. Available from: https://scholar.google.com.br/scholar?hl=en\&as_sdt=0,5\&q=ANTUNES, + C. $+\mathrm{H}$. $\% 3 \mathrm{~B}+\mathrm{PILEGGI},+\mathrm{MAZDA},+\mathrm{A} .+\mathrm{K}$.

+Porque+a+visão+científica+da+microbiologia+não+tem+o+mesmo+foco+na+per cepção+da+microbiologia+no+ensino+ Medium. + minutes + + III + Terce

[14] Welker C A D. The study of bacteria and protists in high school: a less conventional approach. Electronic journal Experiments in Science Teaching, Porto Alegre, 2007, 2: 69-75.

[15]. M F, Barbosa I P J L. Methodological alternatives in Microbiology: enabling practical activities.Journal of Biology and Earth sciences, Campina Grande$\mathrm{PB}, 2010,10$ of them: $134-143$.

[16] Ferreira A F, the importance of microbiology at school: an approach in high schools. Graduation work in biological sciences. State University of Rio de Janeiro,2010,1-56.[Internet]. [Cited 2019 Jun 4] Available from https://www.decb.uerj.br/arquivos/monografias/Andréa Fonseca Ferreira-PPII-the importance of Microbiology. pdf

[17] Cassanti A C, Cassanti A C, Araujo E E, URSI S. Democratic Microbiology: Teaching-learning strategies and teacher training. Encyclopedia Biosphere, 2008, 8: 1-23.

[18] Trabulsi L R, Alterthum F. Microbiology. 4th ed. Atheneu Publishing House; 2004, $402-403$.

[19] Carvalho I T. Food Microbiology. [Agricultural College Dom Agostinho IkasCODAI, Federal University of Pernambuco-UFPRE, Federal University of Rio Grande do Norte-UFRN. E-Tec Brazil, 2010, 25.

[20] Santos A S, Costa I A S. Investigative practice: Experiencing the world of microbiology. 11th National Seminar of High School-UFRN, Mossoró-RN, [Internet].2012. [Cited 2019 Jun 3]; Available from https://repositorio.ufrn.br/jspui/handle/123456789/11855

[21] Camargo F P, Silva A F G, Santos A C. Microbiology in the student's Notebook and textbooks: documentary analysis. Revista Iberoamericana de Educación, 2018, 78 (2): 41-58.

[22] Mora J E, Silva E M, Xavier M. Microbiology: Knowing an unseen world. In: 
Meeting of teaching Research and extension-UEMS [Internet]. 2016 [cited 2019 Jun 4]. P. 7. Annals of Semex, nn. 9,. 65-776. Available from: http://cascavel.ufsm.br/revistas/ojs-2.2.2/index.php/educacaoespecial/article/view/ 7148

[23] Romeiro S S; Sousa L F, Oliveira L S. Microbiology: An approach through practical/experimental classes. Science and Technology Fatec-JB, 2016, 8.

[24] Barbosa F G, Oliveira N C. Strategies for Teaching Microbiology: an experience with elementary school students at an Anápolis-GO school. Journal of Education, Education, and humanities, 2015, 16 (1): 5-13.

[25] Right I C N, Figueiró R, Alves M P, de Oliveira A M D, de Mello M C, Coelho M R G, de Salles J B, Vieira J M B D, da Silva L P, Docile T N, Assis M C. Scientific knowledge in biotechnology of high school students of public schools In the Western zone of Rio de Janeiro/RJ. Revista Práxis, 2014, 6 (11): 115-124.

[26] Teixeira R B, Oliveira S M C. Profile of patients with Chagas disease in Rio Branco, Acre, Brazil. Journal of the Brazilian Society of Clinical Medicine, 2015, 13 (4): 262-5.

[27] Souza L Z, Rodrigues R G A. Souza L Z, Rodrigues R G A, De Oliveira D A D, Roman J L, Zabott $m$ V, Pinto S B, Oyafuso $m$ K. Seroprevalence of Toxoplasma gondii in Cats domiced in Palotina, Paraná, Brazil. Archives of Veterinary Sciences and zoology of UNIPAR, 2017, 20(3).

[28] Romeiro S S, Sousa L F, Oliveira L S. Microbiology: An approach through practical/experimental classes. Science and Technology Fatec-JB, 2016, 8.

[29] Cavalcante, F. S. A., Campos, M. C. C., de Lima, J. P. S., Caminha, I. S. Relação ensino-aprendizagem sobre fungos no ensino superior: um estudo bibliográfico. Ciência e Natura, 2019. 41, 48.

[30] Maximo L L M I, Nathalia m B C, Queiroz m E P, Figueiredo N D. Knowledge about Influenza among health professionals of a general Hospital. Health in networks, 2015, 1 (3): 37-48.

[31] World Health Organization (WHO). Coronavirus disease (COVID 19) Pandemic. 2020. Access on March 22, 2020. Disponible on: https://www.who.int/emergencies/diseases/novel-coronavirus-2019.

[32] Machado, V, Cunha, K M, Peicha, Q C, Sudati, J H, Moraes, M S A. The use of mobile phones as a technology for the teaching of viruses and vectors. Anais do $11^{\circ}$ Salão Internacional de ensino, Pesquisa e Extensão da UNIPAMPA: Salão de Ensino, 2019, 11 (1).

[33] Meira I A, Silva A S, Santos M C, Santos D S, Fortuna J L. Teaching-Learning through laboratory practices of microbiology. Science and Technology Fatec-JB, 2016, 8.

[34] Silva, R C, Silva, M D, Santos, C G. Systematic mapping: methods, 
techniques, and artifacts for the education of microbiology without the use of laboratories. Revista Multidisciplinar de Psicologia, 2019, 1(45) 